\title{
IMPACT OF IRRIGATION IN THE COMMAND AREA OF BAGMATI IRRIGATION PROJECT
}

\author{
Ananta Raj Dahal*
}

\begin{abstract}
As an agrarian economy Nepal, irrigation is most important to achieve economic development. This research analyzes the impact of Bagmati irrigation project (BIP) in the command area. A comparative study of the output, employment, income and other variables related to the irrigated and un-irrigated agricultural land within and outside the Bagmati irrigation project area has led to positive result. This study found that agricultural productivity increases from 19.32 percent to 102.78 percent in different crops. Likewise irrigation seems to have contributed to increase employment, investment, net income.
\end{abstract}

Key Words: Irrigation Command Area, Farm Employment, Farm Budget,

\section{BACKGROUND}

Nepal being an agrarian economy, around 81 percent of its population is employed in agriculture sector. It receives more than 40 percent of its national income from agriculture. Unfortunately, the current growth rate in agricultural production is 2.4 (Government of Nepal, Ministry of Finance, 2054/55). To raise the living standard of the people, it is evident that the improvement in agricultural is inevitable. To increase the agricultural production, in turn, the use of various inputs such as improved seeds, fertilizers, irrigation etc. are essential.

In Nepal more than 50 Percent of cultivated land is used only for seasonal agricultural product. These lands remain idle for 6 months. Consequently the population of unemployment is more severe. If we are able to irrigate agricultural land, employment opportunity can be increased; it will also help to solve the problem of unemployment to a greater extent. Agriculture Perspective Plan has stressed the role of agriculture in generating employment opportunities and improving the living standard of people. This plan has also defined irrigation as a strategic input and has prescribed the conjunctive use of water in Terai region. As the agricultural sector contributes a significant amount to the national income, the change in national income is a direct reflection of the change in agricultural production. When national income increases the per capita income will also increase. This is an effective indicator of economic growth. Thus, it is essential to analyze the parameter of agricultural growth. In this connection, irrigation is one of the most important inputs to increase the agricultural

\footnotetext{
${ }^{*}$ Mr. Dahal is Assistant Lecturer of Economics at Patan Multiple Campus, Tribhuvan University, Nepal
} 
product particularly in the following two grounds. Firstly, we can increase the agricultural product in the cultivated land with irrigation by enhancing the efficiency of rest auxiliary inputs. And, secondly, we can extensively cultivate the uncultivated agricultural land providing irrigational national facilities.

The total irrigable land in Nepal is estimated to be 2.18 million ha. Out of this 1.74 million ha. is in the plains of Terai region and rest 0.44 million is situated in the valleys of the hill. Out of this potential irrigable areas, just 1.766 million ha. has been provided irrigation. Moreover out of which some 1.06 million ha. are already developed (i.e. provided with infrastructure) for irrigation. Of the latter figure, however, only about 71 percent is actually irrigated. That leaves some 29 percent of the developed command area that could be brought under irrigation with relative ease, in addition to the nearly 700,000 ha. yet to be developed for irrigation. Areas covered by surface and ground water irrigation are 854,000 and 206,000 ha. respectively and representing 80.6 percent and 19.4 percent respectively of the total irrigated area.

The reported physical development of irrigation has been a subject of review since the targets of agricultural development envisaged in the feasibility study report were not met. Bagmati irrigation project is a large irrigation project and its performance to a greater extent may represent the performances of other larger surface irrigation project. Therefore, this study is based on Bagmati Irrigation Project(BIP). A review of such project is essential in order to make them more productive. Such review also warns us not to commit similar mistakes in the future. In this backdrop, this paper aims at assessing the impact of irrigation in the command area of BIP. Specifically this paper aims to measure the contribution of irrigation in increasing agricultural productivity and employment in and around the Bagmati Project area.

\section{REVIEW OF LITERATURE}

Although irrigation and water resources has been the subject of study for a long time, systematic attempts measuring the effect of the irrigation project on agricultural productivity, employment, and responsiveness of co-operating factors in an integrated manner is scarce. Here some of the available and relevant previous studies have been reviewed in order to be familiar with the works done earlier. In the review, more attention has been given to the objectives, methodology and findings.

Raut (1987) made a case study of Manusmara Irrigation project of Sarlahi district. The main objective of the study was to analyze Manusmara irrigation project in the light of the co0jntribution made by it to wellbeing of the agricultural peasants. To fulfill the objective, the researcher has used cost benefit analysis method to analyze the data collected through primary and secondary sour4ces. It was found that the cost benefit ration more than unity. So, it was concluded that the project was financially feasible and it could benefit the farmers residing in the project area. 
One more Impact Evaluation Study of Mahakali Irrigation Project was done by Mahakali Irrigation Project (1985). The main objective of this study was to evaluate the contribution of irrigation project in agricultural development, to study the impact of the project and to study the problems associated with full utilization of irrigation. To meet his objective, the primary data was collected through the cross-sectional method. The finding of this study indicated that this irrigation project had increased the productivity of land and increased the framers' production, investment and employment and also it helped to cultivate the uncultivated land. It also helped to increase the price of land. Thus, this study showed the positive impact of the project in the project area.

Lamsal (1989) made a study on Impact of Vijayapur Begnas Irrigation Project in Pokhara valley as a case study of Lekhanath and Roki Millage Panchayat. The main objectives of this study was to find out the impact of irrigation of the cultivated land of that area and to analyze the changes in the production of various crops and price of land after irrigation facility. It used both primary and secondary data to conduct this study. A comparison between the productions, investments and employment of irrigated and un-irrigated land was made. This study found that the project increased the production of the area. It helped to cultivate the uncultivated land increased productions. Analysis on investments and employment of irrigated and un-irrigated land was made. Irrigation facility helped to cultivate the uncultivated land, and to increase the price of the agricultural land. So the impact of this project was positive.

Gelal (1994) made a study on Problem of Water-Resources Management in Jhukhal with the main objectives of (a) assessing the present day water management practice; (b) analyzing the available source of water supply and quantity of water in village; (c) presenting the demand scenario of water to examine the cases of water shortage; (d) performing economic analysis of water resource project; and (e) suggesting economic measures for the better management. This study used Cost Benefit Analysis method. It found that it was necessary to control the leakage and wastage of water, which helped to increase water supply to the growing population. To meet demand for water, it was necessary to search new sources of water supply. Government should provide piped drinking water facility. To regulate the irrigation system of the village, canal must be built using the sources of Monahare Khola.

Similarly Shrestha (1989) studied the community managed irrigation systems in Arughat Vishal Nagarpipe Irrigation Project. The main objectives of this study were to find the benefit of the local economy, find the impact in terms of cropping patterns, input demand and community participation. It used primary data. It found that this project increased land productivity of the area. The study also indicated that to take full advantage of the irrigation, there should be no shortage of improved seeds and fertilizers in the project area. 
A feasibility study for the Rajapur Irrigation Rehabilitation project was made by EURO consult, the Netherlands Incorporation with APROSC Nepal (1990). The main objectives of this study were to identify the critical issues and problems related to water resources, irrigation, agriculture and socio-economic constraints and give direction to further feasibility investigations during stage 2 . For the analysis, both the primary and secondary data were used. The results obtained that irrigation had positive impact of productivity, cultivation and price of land. It also increased agricultural employment. So this report showed that this irrigation project had positive impacts in all respects.

Dhital (1983) assessed the socio-economic condition of households within Puwa Khola Irrigation Project in Ilam. The main objectives of this study are to assess the socioeconomic condition of the households within the command area. It used both primary and secondary data in the course of analysis. Its findings showed that this project positively affected the socio-economic condition of the people of that area in terms of production, employment, income and investment. In aggregate, this project played significant role to uplift the economic status of the local people.

\section{RESEARCH METHODOLOGY}

Both descriptive as well as explanatory research method were used for the data analysis. The descriptive methodology is in the sense of describing the existing situation of the issue where as exploration means the prediction of the future prospect. The study is based on primary sources of information. To collect such information 50 households having irrigated land and 25 households having un-irrigated lands were selected as samples for household survey on the basic of simple random sampling. The geographical locations of survey were Chandranigahapur and Santapur Village Development Committees (VDCs) of Rautahat district of Nepal. The equal number of household are selected form the both VDCs. For the qualitative information, the civil servants, member of VDCs, teachers and local intellectuals were also interviewed.

Relevant secondary data and information were collected from various government offices like Development of Irrigation, Bagmati Irrigation Project office, District Irrigation Office, VDC offices of Chandranigahapur and Santapur VDCs and used according to their need.

In this research multiple ordinary least square (OLS) regression model was used to get the expect result. To apply regression technique the collected data were processed using software like Excel and SPSS. To see the responses of inputs in irrigated and unirrigated agricultural land, the following functions were considered.

For irrigated Land $\left(\mathrm{O}_{\mathrm{i}}\right)=\mathrm{f}(\mathrm{L}, \mathrm{S} . \mathrm{F})$

And for unirrigated Land $\left(\mathrm{O}_{\mathrm{ui}}\right)=\mathrm{f}(\mathrm{L}, \mathrm{S} . \mathrm{F})$

where $\mathrm{O}=$ Return from Land, $\mathrm{L}=$ Labour, $\mathrm{S}=$ Seeds, and $\mathrm{F}=$ Fertilizers 
The linear regression model is specified as:

$$
\begin{aligned}
& \mathrm{O}_{\mathrm{i}}=\mathrm{a}_{\mathrm{o}}+\mathrm{a}_{1} \mathrm{~L}+\mathrm{a}_{2} \mathrm{~S}+\mathrm{a}_{3} \mathrm{~F}+\mathrm{U}_{1} \\
& \mathrm{O}_{\mathrm{ui}}=\mathrm{a}_{\mathrm{o}}+\mathrm{a}_{1} \mathrm{~L}+\mathrm{a}_{2} \mathrm{~S}+\mathrm{a}_{3} \mathrm{~F}+\mathrm{U}_{1}
\end{aligned}
$$

In both of regression models $\mathrm{a}_{\mathrm{o}^{\prime}} \mathrm{a}_{1^{\prime}} \mathrm{a}_{2^{\prime}} \mathrm{a}_{3}$ are the parameter where are $\mathrm{U}_{1}$ is the error term. All these parameters are estimated by Ordinary Least Square (OLS) method. For this SPSS software is used.

\section{ANALYSIS AND INTERPRETATION}

The irrigation has positive impact on agricultural production, farm income and employment. But the extent of impact depends on various factors such as cropping intensity, crop type, management of irrigation facilities, farming technology etc. Therefore, the impact may vary by place to place and project to project. The primary data collected within the outside the Bagmati Irrigation Project command area that could determine the impact of irrigation in following ways:

\section{a) Effect of Irrigation on Total Output}

A comparison of total outputs of irrigated land and non-irrigated land indicates that there is more production in irrigated land than in non-irrigated land as shown in Table 1.

\begin{tabular}{|c|c|c|c|c|}
\hline \multirow[b]{2}{*}{ Crops } & \multicolumn{4}{|c|}{ Total Output (kg) } \\
\hline & $\begin{array}{l}\text { Without } \\
\text { Irrigation }\end{array}$ & $\begin{array}{c}\text { With } \\
\text { Irrigation }\end{array}$ & $\begin{array}{l}\text { Change } \\
\text { in Total }\end{array}$ & $\begin{array}{c}\% \\
\text { Change }\end{array}$ \\
\hline Paddy (Rain Seasons crops) & 1542.40 & 2182.40 & 640.00 & 41.49 \\
\hline Wheat (Winter Crops) & 1323.00 & 1625.05 & 302.05 & 22.83 \\
\hline Maize (Winter Crops) & 673.75 & 887.81 & 214.06 & 31.77 \\
\hline Other (Winter Crops) & 248.36 & 417.22 & 168.86 & 67.99 \\
\hline Total & 3787.50 & 5112.48 & 1324.98 & 34.98 \\
\hline
\end{tabular}

Table 1: Effect of Irrigation on Total Output

Source: Field Survey, 1999. Note: Other crops include Mustard, Dalhan etc.

From Table 1, we come to know that there is $34.98 \%$ increase in the total production with irrigation facility. Among the four cultivated crops, mustard and oil-seeds have been found more affected by irrigation. The productions of mustard and oil-seeds have increased by $67.99 \%$ in irrigated land compared to their production in non-irrigated land. The production of paddy, on the other hand, has also increase by 41.49 percent. Because of the availability irrigation facility, there has been possible to cultivate some of the agricultural lands three times a year. Thus, Bagmati Irrigation Project has increased the total production of farmers significantly. 


\section{b) Effect of Irrigation on Farm Income}

The agricultural production has been increased in irrigated land as reflected in Table 2. To get farm income, the annual physical productions of both irrigation and nonirrigated lands have been converted into monetary term.

Table 2: Effect of Irrigation on Farm Income

\begin{tabular}{lrrrr}
\hline \multirow{2}{*}{\multicolumn{1}{c}{ Crops }} & \multicolumn{4}{c}{ Farm Income } \\
\cline { 2 - 5 } & $\begin{array}{c}\text { Without } \\
\text { Irrigation }\end{array}$ & $\begin{array}{c}\text { With } \\
\text { Irrigation }\end{array}$ & $\begin{array}{c}\text { Change } \\
\text { in Total }\end{array}$ & $\begin{array}{c}\% \\
\text { Change }\end{array}$ \\
\hline Paddy (Rain Seasons crops) & 7021.00 & 14885.50 & 7864.50 & 112.014 \\
Wheat (Winter Crops) & 7413.00 & 10783.5 & 3370.50 & 45.46 \\
Maize (Winter Crops) & 5143.00 & 7742.00 & 2599.00 & 50.53 \\
Other (Winter Crops) & 3769.00 & 7643.00 & 3874.00 & 102.78 \\
Total & 23346.00 & 41054.00 & 17708.00 & 75.85 \\
\hline
\end{tabular}

Source: Field Survey, 1999. Note: Other crops include Mustard, Dalhan etc.

If we calculate the farm income of farmers, we find that their income altogether has increased by $75.85 \%$ by crop; the increase in the terms of financial analysis of paddy is by $112 \%$. Paddy is planted in summer season and it needs much water. Summer season is the suitable season for paddy in Nepal. The area without irrigation can have two crops but with irrigation three crops. In case of wheat and maize production, the farm income has increased by $45.46 \%$ and $50.33 \%$ respectively. The increase is even more in case of mustard and other oilseeds $(112.78 \%)$.

\section{c) Effect of Irrigation on Farm Employment}

The provision of irrigation has brought a number of opportunities of employment for the farmers. This is clearly obvious from the comparison of the levels of employment associated with the land with irrigation and without irrigation as given in Table 3.

Table 3: Effect of Irrigation on Farm Employment

\begin{tabular}{lrrrr}
\hline \multirow{2}{*}{\multicolumn{1}{c}{ Crops }} & \multicolumn{4}{c}{ Farm Income } \\
\cline { 2 - 5 } & $\begin{array}{r}\text { Without } \\
\text { Irrigation }\end{array}$ & $\begin{array}{c}\text { With } \\
\text { Irrigation }\end{array}$ & $\begin{array}{c}\text { Change in } \\
\text { Total }\end{array}$ & $\begin{array}{c}\% \\
\text { Change }\end{array}$ \\
\hline Paddy (Rain Seasons crops) & 99.76 & 113.62 & 13.62 & 13.68 \\
Wheat (Winter Crops) & 66.15 & 64.99 & $(-1.16)$ & $(-1.78)$ \\
Maize (Winter Crops) & 35.38 & 61.68 & 26.3 & 74.33 \\
Other (Winter Crops) & 33.18 & 38.02 & 4.84 & 14.58 \\
Total & 234.47 & 278.07 & 43.6 & 18.59 \\
\hline
\end{tabular}

Source: Field Survey, 1999. Note: Other crops include Mustard, Dalhan etc. 
The land with irrigation provides more employment than the land without irrigation. Our data show that the employment in paddy cultivation in irrigated land increased by 13.65 percent. But in case of wheat the level of employment has decreased by 1.78 percent. This may be due to the use of previously wheat-cultivated-land for the cultivation of other crops like paddy. The other reason is that farmers used modern agricultural tools such as tractor to plough and thrasher to thresh the wheat. This also led to the decrease in level of employment. In case of maize, the employment level increase by $74.33 \%$ with irrigation facility.

\section{d) Incremental Return of Farm}

Production cost and the farm output in both irrigated and un-irrigated land ism given in Table 4.

Table 4: Incremental Return of Farmers

\begin{tabular}{lcrrrrrrrrr}
\hline \multirow{2}{*}{\multicolumn{1}{c}{ Crops }} & \multicolumn{2}{c}{ Farm Cost } & \multicolumn{3}{c}{ Farm Income } & Net Return & \multicolumn{2}{c}{$\begin{array}{c}\text { Incremental } \\
\text { Return }\end{array}$} \\
\cline { 2 - 12 } & A & B & A & B & A & B & A & B \\
\hline Paddy (Rain Seasons crops) & 8892 & 9667 & 15912 & 24552 & 7020 & 8640 & 1620 & 23.076 \\
Wheat (Winter Crops) & 5818 & 5468 & 13230 & 16251 & 7412 & 10783 & 3371 & 45.48 \\
Maize (Winter Crops) & 2147 & 3232 & 5391 & 7103 & 3244 & 3871 & 627 & 19.32 \\
Other (Winter Crops) & 2440 & 2788 & 6209 & 10431 & 3769 & 7643 & 3874 & 102.78 \\
\hline
\end{tabular}

Source: Field Survey, 1999. Note: 'A' stands without irrigation and B stands for with irrigation. Other crops include Mustard, Dalhan etc.

It is obvious that there is more production in an irrigated land. According to the table the incremental return of paddy, wheat, maize and other crops is Rs.1620, Rs.3371, Rs.627 and Rs.3878 in respectively and in percent they are 23.076, 45.48, 19.32 and 102.78 per bigha respectively. Farmers cultivate only two crops in an un-irrigated land in a year but they can cultivate three crops in the irrigated land. As a result the additional crop can increase farmers' income. Thus irrigation has increased farmer's net return.

\section{e) Farm Budget}

Irrigation has played a vital sole in the investment of peasants. Total investment and income of farmers is shown in Table 5. 
Table 5: Total Investment and Income of Farmers

\begin{tabular}{lcccccc}
\hline \multirow{2}{*}{ Crops } & \multicolumn{3}{c}{ Investment (Cost of Production) } & \multicolumn{2}{c}{$\begin{array}{c}\text { Income (Production) } \\
\text { (in Rs) }\end{array}$} \\
\cline { 2 - 7 } & Seed & Fertilizer & Labour & Total & Production & $\begin{array}{c}\text { Net } \\
\text { Income }\end{array}$ \\
\hline $\begin{array}{l}\text { Without Irrigation } \\
\text { Paddy (Rainy Seasons) }\end{array}$ & 628 & 3275 & 4988 & 8891 & 15912 & 7021 \\
With Irrigation & 501 & 3366 & 5799 & 9666 & 24552 & 14886 \\
\hline Without Irrigation & 978 & 2550 & 3169 & 6697 & 13230 & 6533 \\
Wheat (Winter Crops) & 1041 & 1176 & 3249 & 5466 & 16250 & 10784 \\
With Irrigation & 273 & 104 & 1769 & 2146 & 5390 & 3244 \\
\hline Without Irrigation & 291 & 200 & 3084 & 3575 & 7102 & 3527 \\
$\begin{array}{l}\text { Maize (Winter Crops) } \\
\text { With Irrigation }\end{array}$ & 690 & 91 & 1659 & 2710 & 6209 & 3499 \\
\hline Without Irrigation & 756 & 37 & 2009 & 2802 & 10431 & 7629 \\
$\begin{array}{l}\text { Other (Winter Crops) } \\
\text { With Irrigation }\end{array}$ & & & & & & \\
\hline
\end{tabular}

Source: Field Survey, 1999. Note: Other crops include Mustard, Dalhan etc.

This table has also shown the production and net profit of peasants. After the irrigation, production has $n$ increased and net profit has also increased. In the non-irrigation sector paddy is sold in Rs. 7021 but in the irrigation sector, they have got Rs. 14886 net income. Thus, irrigation has increased the income of peasants by double. Different types of crops like paddy, wheat, maize and others have been increased by irrigation from the peasants' income side, irrigation has played positive hold. They are eager to invest their asset in irrigation because after the irrigation, they have got increased income. Investment is increased in paddy and corn but the same thing is not found in wheat. Low investment in wheat is the result of modern technical system in farming. Now peasants are using their capital not labours. This process has reduced the investment.

\section{f) Change in Output With and Without Irrigation}

The effect of irrigation on output is shown in Table 6.

Table 6: Change in Output with and without Irrigation

\begin{tabular}{lrrrr}
\hline \multirow{2}{*}{ Crops } & \multicolumn{4}{c}{ Farm Income } \\
\cline { 2 - 5 } & Without & With & \multicolumn{2}{c}{ Different between } \\
& Irrigation & Irrigation & Change in Total & \% Change \\
\hline Paddy (Rain Seasons) & 1542.40 & 2182.40 & 640.00 & 41.49 \\
Wheat (Winter Crops) & 1323.00 & 1625.05 & 302.05 & 22.83 \\
Maize (Winter Crops) & 673.75 & 887.81 & 214.06 & 31.77 \\
Other (Winter Crops) & 248.36 & 417.22 & 168.86 & 67.99 \\
Total & 3787.51 & 5112.48 & 1324.97 & \\
\hline
\end{tabular}

Source: Field Survey, 1999.Note: Other crops include Mustard, Dalhan etc. 
The comparison shows that output is more on irrigated land than in land without irrigation. The production of paddy is $1542.40 \mathrm{~kg}$. per bigha, wheat is $1323 \mathrm{~kg}$., maize is $677375 \mathrm{~kg}$., and $248.36 \mathrm{~kg}$ per Bigha. But in irrigated land production of paddy is $2182.40 \mathrm{~kg}$., wheat $162505 \mathrm{~kg}$., maize - $887.81 \mathrm{~kg}$., and others $417.22 \mathrm{~kg}$ per Bigha. All the production has increased due to irrigation as shown in the table. The productions of paddy, wheat, maize, and other crops have increased by 640, 302.05, 214.08 and $168.86 \mathrm{~kg}$., respectively. If we express the increases into percent, they will be 41.19 , $22.83,31.77$ and 67.99 percent respectively. Output has been increased incase of all crops but the output of other crops and paddy has highly increased. Thus irrigation has brought positive change in farming.

\section{g) Input Response in Irrigation and Un-Irrigated Land}

To find out the input response in irrigated and un-irrigated land, regression models for each scenario was run. In the inputs, labour, seeds and fertilizers are considered. Return from the agricultural land is taken to be the dependent variable whereas the inputs are independent variables.

\section{Model - 1: Input output relationship in irrigated land}

Followings are the results of the simple and multiple regression models. In the equation, $\mathrm{R}=$ return, $\mathrm{L}=$ labour, $\mathrm{S}=$ seeds, and $\mathrm{F}=$ fertilizers.

\section{Case: 1}

$\mathrm{R}=20733.688+1.315 \mathrm{~L}+2.005 \mathrm{~S}-2.2487 \mathrm{~F}$

$\mathrm{t}=(2.726) \quad(2.342) \quad(0.557) * *(2.241)$

$\mathrm{F}=(7.329)^{*} \quad \mathrm{r}^{2}=0.323$

${ }^{*} \mathrm{~F}$ value is highly significant at 0.000 significant level.

** $\mathrm{T}$ value is found insignificant at 1,15, 10 percent significant level. All other $\mathrm{t}$ - values are found significant below $5 \%$ significant level.

The coefficient of seed is found to be insignificant at 1, 5 and $10 \%$ significance level, which indicates that the increase in the seeds may not bring increase in return as per its coefficient. The value of $\mathrm{R}^{2}$ is found to be 0.323 only, which indicates that the model is not best fitted which would mean that there are so many other significant variables which influence the returns from the land except these labour, seeds and fertilizer. This value indicates that only $32.3 \%$ variation is explained by labour, seeds are fertilizers, and $67.7 \%$ of $\mathrm{R}$ is explained by variables other than included in the model. However, the value of $\mathrm{F}$ is found highly significant at $(3,4$, and 6$)$ degree of freedom which implies that there is good linear relationship between returns and labour, seeds and fertilizer. 


\section{Case: 2}

$$
\begin{array}{ll}
\mathrm{R}=29238.332 & 1.823 \mathrm{~L} \\
\mathrm{t}=(4.636) & (3.816) \\
\mathrm{F}=(14.583) & \mathrm{r}^{2}=0.233
\end{array}
$$

F is found highly significant at 0.000 levels.

t-statistic is also sound to be highly significant at 0.000 significant levels.

The coefficient of labour is found to be highly significant at 0.000 significant level. Thus, if we increase L by unity the returns from the land would increase by 1.823 times, The value of $R^{2}$ in this case is 0.233 which implies that only the $23.3 \%$ of variation in famers return ( $R$ ) is explained by $L$ and the remaining $76.77 \%$ variation of $R$ is explained by other variables. However the value of $\mathrm{F}$ is found highly significant at $(1,48)$ degree of freedom which implies that the there is good linear relationship between returns and labour.

\section{Case: 3}

$\mathrm{R}=31159.847+9.284 \mathrm{~S}$

$\mathrm{t}=(4.046)^{*}$

$\mathrm{F}=(8.079)$

$(2.842)^{*}$

$r^{2}=0.144$

$\mathrm{t}^{*}$ is found significant at 0.007 percent significant level.

$\mathrm{F}$ is also found to be significant at 0.007 percent significant level.

The coefficient of seed is found to be highly significant at 0.007 percent significant level. Thus unitary increase in quality of seeds would cause to rise in returns from land by its coefficient times. The value of $\mathrm{r}^{2}$ in this case is 0.144 , which implies that only the $14.4 \%$ returns $(\mathrm{R})$ is explained by Seeds. However, the value of $\mathrm{F}$ is found highly significant at $(1,48)$ degree of freedom. This implies that there is a good linear relationship between the variables.

\section{Case: 4}

$\mathrm{R}=37559.506+3.267 \mathrm{~F}$

$\mathrm{t}=(7.644)^{*} \quad(3.239)^{*}$

$\mathrm{F}=(10.491)^{*} \quad \mathrm{r}^{2}=0.179$

${ }^{*}$ Both $\mathrm{t}$ and $\mathrm{F}$ are found significant at 0.002 percent significant level.

In this case also the coefficient of fertilizer is found to be significant at 0.002 percent significant level. The value of $\mathrm{r} 3=0.173$ shows that only $17.3 \%$ of $\mathrm{R}$ is explained by fertilizers. $\mathrm{F}$ is also found to be significant at $0.002 \%$ significant level that means there is the good linear relationship between the variables. 


\section{h) Model-2: Input output relationship in un-irrigated land}

\section{Case: 1}

$\mathrm{R}=23891.521+0.536 \mathrm{~L}+1.05909 \mathrm{~S}-0.0487 \mathrm{~F}$

$\mathrm{t}=(2.47)^{*}(0.688)$

$\mathrm{F}=(0.37124)^{* *} \quad \mathrm{r}^{2}=0.05537$

*t is found significant at 0.02 significant level, all other $t$-values are found insignificant.

${ }^{* *} \mathrm{~F}$ is found insignificant at the conventional level of significance (i.e., F-statistics is insignificant at 1\%,5\% and 10\% level of significance).

The coefficient of each of the independent variables is found insignificant. The sign coefficient of fertilizer $(\mathrm{F})$ is unexpectedly negative. The value of $\mathrm{F}$ is also found to be insignificant at $(3,19)$ degree of freedom, which implies that there may not be good linear relationship between the dependent and independent variables.

\section{Case: 2}

$\mathrm{R}=25884.92+0.573 \mathrm{~L}$

$\mathrm{t}=(4.415)^{*} \quad(0.945)^{* *}$

$\mathrm{F}=(0.893)^{* * *} \quad \mathrm{r}^{2}=0.0373$

$\mathrm{t}^{*}$ is found significant at 0.0002 significant level but coefficient of labour(L) is found insignificant at the conventional level of significance.

$\mathrm{F}^{* *}$ is found insignificant at $(1,23)$ degree of freedom.

\section{Case: 3}

$\mathrm{R}=27406.604+1.7512 \mathrm{~S}$

$\mathrm{t}=(5.41) \quad(0.793)^{*}$

$\mathrm{F}=(0.629)^{* *} \quad \mathrm{r}^{2}=0.02663$

${ }^{*}$ Coefficient is found insignificant as indicated low t-statistics

${ }^{* *} \mathrm{~F}$ is found significant at 0.4358 significant level, i.e., it is insignificant at $(1,23)$ degree of freedom.

\section{Case: 4}

$\mathrm{R}=32198.928-0.36074 \mathrm{~F}$

$\mathrm{t}=(6.265)$

$\mathrm{F}(0.0657)^{*}$

$(-0.258)^{*}$

$\mathrm{r}^{2}=0.0031$

*t is found highly insignificant

${ }^{* *} \mathrm{~F}$ is found insignificant at 0.8001 insignificant level, i.e., it is found highly insignificant at (1.21) degree of freedom. 
In each of the above model both $\mathrm{t}$ and $\mathrm{F}$ are not found to be insignificant which indicates that of the independent variable properly influences the dependent variables nor is there any linear relationship between them.

To summarise, the explanatory variables are found to be more powerful to explain the dependent variable in case of irrigated land. In the first model, whatever be the value of $\mathrm{R}^{2}$, there is the good relationship between the dependent and independent variable which is shown by the value of F-statistic. However, it is very difficult to find the linear relationship between the dependent and independent variable in the second model. The more interesting result is in the mode II case 4 in which the coefficient of $\mathrm{F}$ is negative. This indicates that if we increase the fertilizer the return from land will decrease. This may happen in the particular land where if we increase the fertilizer in the un-irrigated land more than the dose scientifically prescribed, the crops from the land may die. As a result the returns may decrease. We found that all the input variables are more powerful in irrigated land than in un-irrigated land.

To conclude the analysis we must disclose the fact though there is a positive impact of irrigation on different aspects of farmers earning and input use, there is still a divergence between the Bagmati Irrigation Project (BIP)'s expected and realized increase in agriculture production.

\section{CONCLUSION}

In the command area of BIP the irrigation has contributed to the increase in crop production at different range. The lowest rate of increase in wheat production is 22.83 percent and highest rate of increase in other crop production is 67.99 percent. So, irrigation has highly positive impact on total agricultural production.

Irrigation has positive impact on farm income too. The lowest rate of increase in farm income from wheat is 45.46 percent and a highest rate of increase from paddy is 112.014 percent.

The comparative study of crops in lands with and without irrigation indicates that the outputs of all crops have increased with irrigation but the rate of increase in paddy and other crops are more or less same as the farm employment before and after irrigation. It becomes clear that the employment situation of farmers improved significantly due to the increase in cropping intensity. From the comparative study of farm it appears that there is increase in return, the lowest return from the maize is 19.32 percent and the highest return from the other crops is 10.278 percent.

The study showed that this BIP irrigation project has increased net income of farmers and this project also played a vital role to increase price of land too. After the implementation of this project the price of land has increased from time to time. 


\section{References}

CBS (1991/92). National sample census of agriculture Nepal, ecological belt mountain, Nepal. Kathmandu. Author

Agricultural Development Council (1976). An introduction to agricultural extenuation. New Delhi

APROCS (1986). Socio-economic benchmark study of Mahakali irrigation project. Kathmandu

APROCS (1987). Irrigation impact evaluation study Mahakali irrigation project. Kathmandu

CBS (1991/92). National sample census of agriculture Nepal, ecological belt terai, Nepal. Kathmandu: Author

Dangal, S. (1990). Role of hydropower for economic development in Nepal. Kathmandu: APROCS.

Dhital, S. (1983). Puwa Khola Irrigation Project, Ilam. Kathmandu: APROCS.

ELIRO Consult the Netherland in Co-operation with APROSC (1990). Feasibility study for the Rajapur irrigation rehabilitation Project. Kathmandu

Gautam, S. R. \& Shrestha, P.B. (1997). Technological constraints to the optimum utilization and expansion of ground water irrigation in terai, Nepal. Kathmandu: Win rock International.

Gelal P.R. (1994). A study of problem of water resource management in Jhukel, (Unpublished M.A. thesis submitted to the Department of Economics). Patan Multiple Campus.

Government of Nepal, Ministry of Finance (2055). Economy Survey FY 2054/55). Author

Guragain, U. (1989). Rapti valley project with special reference to Chitwan valley, Nepal. Kathmandu Irrigation Department.

ICIMOD (1991). Review of institutional capacities for sustainable mountainous agricultural development. Kathmandu. Author

IMC Pokhara Nepal (1990). Irrigation efficiency during early paddy cultivation at Malebage farmers managed irrigation system: A study report on water management aspect under action research program. Kathmandu: APROSC.

Irrigation Department (1996). Eastern regional irrigation directorate district irrigation office Sunsari. Author

Irrigation Department (1990). Design manuals for irrigation project in Nepal. Kathmandu: Author

Irrigation Department (1990). Rupani Nadi irrigation project. Kathmandu: Author 
Irrigation Department (1992). Sub- project feasibility study, Haripurwa irrigation subproject, Sarlahi district Volume I \& II. Kathmandu: Author

Irrigation Department (1993). Central regional irrigation directorate. District Irrigation Office, Mahottari. Author

Irrigation Department (1995). Update master plan for irrigation development in Nepal. Kathmandu: Author

Irrigation Department (1996). Base line study of the Panchya Kanya irrigation system final report. Kathmandu: Author

Irrigation Department, (1992). Draft report Sukumari irrigation project, Sunsari district. Kathmandu: Author

Koirala, G. P. (1995). Clogs in shallow ground water use. Kathmandu: Win rock International.

Koirala, R.P. (1992). Nepalese role in collective use of its water resource. Kathmandu: Win Rock International.

Lamsal, K.P. (1989). Impact of Vijayapur Begn irrigation project in Pokhara: A case study of Lekhanath and Raki village Panchayat. Kathmandu: APROSC.

Meier, G. M. (1971). Leading issues in economic development: Studies in international poverty. Oxford: Oxford university press

Mellor, D.W. (1996). The economics of agricultural development. New York.

Ministry of Agriculture, HMG/N. (1995/96). Statistical information of Nepalese agriculture. Kathmandu: Author

Mosher, A.T. (1995/96). Agricultural handbook of Nepal. Kathmandu: Ministry of Agriculture.

Panta Y.P. \& Jain, S.C. (1962). Agricultural development in Nepal. Kathmandu.

Pradhan, R.R. (1987). A case study of Manusmara irrigation project of Sarlahi district. (An unpublished thesis submitted to the Central Department of Economics), Tribhuvan University. Kirtipur.

Shrestha, B.P. (1974). An introduction to Nepalese economy. Kathmandu, Nepal.

Shrestha, S.P. (1997). Community managed irrigation system: a case study of Arughat-Vishal Nagar pipe irrigation project. Kathmandu: Win Rock International.

Walter, C.E (1973). Irrigation and agricultural development in Asia. Oxford University Press.

WECS/HMGN (1999). Report on feasibility level analysis (updating parameters) of Bagmati multipurpose project. Kathmandu: Author 